 \\ JDss | Journal of Development and Social Sciences WWW.Jdss.01'., $1 \mathrm{k}$ \\ RESEARCH PAPER
}

\section{English for Medical Officers: A Case of ESP}

\author{
${ }^{1}$ Iram Rubab* ${ }^{2}$ Faiza Masood ${ }^{3}$ Dr. Muhammad Arshid Javaid
}

1. Assistant Professor, Department of English, GC Women University, Sialkot, Punjab, Pakistan

2. Ph. D Scholar, Department of English, Bahauddin Zakariya University, Multan, Punjab, Pakistan

3. Lecturer, Department of Education, University of Education, Lahore, Sub Campus D G Khan, Punjab, Pakistan

\begin{tabular}{|c|c|}
\hline IPER INFO & ABSTRACT \\
\hline $\begin{array}{l}\text { Received: } \\
\text { July } 10,2020 \\
\text { Accepted: } \\
\text { August } 25,2020 \\
\text { Online: } \\
\text { September } 30,2020 \\
\end{array}$ & $\begin{array}{l}\text { The undertaken study intends to carry out the needs analysis of } \\
\text { medical officers and to suggest a needs oriented course to meet the } \\
\text { professional requirements. In this regard, insights are taken from the } \\
\text { literature of English for Specific Purposes (ESP) and English for } \\
\text { English for occupational purposes (EOP). So far, the medical }\end{array}$ \\
\hline $\begin{array}{l}\text { Keywords: } \\
\text { English for Specific } \\
\text { Purposes (ESP), } \\
\text { English for Medical } \\
\text { Purposes (EMP), } \\
\text { English for } \\
\text { Occupational } \\
\text { Purposes (EOP) }\end{array}$ & $\begin{array}{l}\text { profession is concerned; medical practitioners need English language } \\
\text { in their professional context. This research is a survey based and it } \\
\text { investigated the communicative needs of the medical officers at a } \\
\text { professional level. The research data was collected, quantitatively } \\
\text { analyzed and interpreted by administering questionnaire among } 100 \\
\text { medical officers of different hospitals of Baluchistan. The findings }\end{array}$ \\
\hline $\begin{array}{l}\text { *Corresponding } \\
\text { Author: } \\
\text { iram.rubab@gcwu } \\
\text { s.edu.pk }\end{array}$ & $\begin{array}{l}\text { showed that the medical officers do not possess required proficiency } \\
\text { of English language skills in the professional context. Finally, specific } \\
\text { field oriented English language courses in order to effectively meet } \\
\text { their communicative needs in professional target settings }\end{array}$ \\
\hline
\end{tabular}

\section{Introduction}

Although there are multiple international languages in the world, English language is playing significant role in the educational and occupational context. In Pakistan, English language has acquired the status of second official language whereas on the international level, it is considered as the international language. English language is also considered the language of technology, media and science. The learning of English language is equivalent to learning different skills of life and this learning takes place while considering the needs of a specific field. This kind of learning is termed as English for Specific Purposes (ESP). English for Occupational Purposes (EOP) and English for Medical Purposes (EMP) are two sub-types of English for Specific Purposes (ESP) and they are also important part of this study.

In Pakistan, the entire medical literature is published in English language. In the professional and occupational context, English language is compulsory for doctors and medical officers regarding conferences, seminars, meetings, communication with foreign patients and for research publications. The study examines the English language needs of 
medical officers and through considering their specific needs, a course is designed for them. For designing a course, it is important to consider the point of view of medical officers. The communicative needs of the medical officers are determined in the study while employing course design strategy and ESP specified needs analysis.

Kang (2004) claimed that as complete medical information is available in English language so, learning English is essential for medical professionals. According to Kurfurst (2004) as most of the documents, books, journals and articles contain information in English language therefore, it is important for medical professionals to maintain command on English language. Further, it plays a significant role in their medical careers and in this way EMP (English for Medical Purposes) became essential. English for Medical Purposes (EMP) is one of the sub-types of English for Specific Purposes (ESP) and is also important for medical professionals regarding their professional needs. Niazi (2012) asserted that in medical context of Pakistan, English language has acquired an unquestionable status. Thus, considering the medical situation in Pakistan, there are multiple professional settings that completely rely on English language. In Pakistan, the medical officers have strong needs to learn (EMP) English for Medical Purposes (p.3). In this regard, the following research questions are generated:

- What are the English language needs of the medical officers in their professional context?

- What kind of ESL course can be designed relying on the information of the present study?

\section{Literature Review}

The literature with reference to English for Medical Purposes (EMP) is presented in three sections:

\section{ESP and Medical Discourse}

"ESP is rightly defined in order to meet the specific needs of the learners" (Rameirez, 2015, p.2). In the words of Smoak (2003), "ESP is task oriented, needs based, and instruction based considering the immediate and actual needs of the learners" (p.27). Mackay \& Mountford (1978) highlighted that ESP courses are designed to serve a "utilitarian purposes" and this shows the clear distinction between EGP and ESP. On the other hand, Crystal (1996) makes it clear that maintaining a general level of proficiency is the main aim of EGP. Though, in the view of Hutchinson \& Waters, the main difference between General English and ESP is "not the existence of need rather than an awareness of the need". The distinction is "there is a great deal in practice whereas there is nothing in theory" (Hutchinson \& Waters, 1987, p. 53). Frinculescu (2009) considered "English as a Lingua Franca" because of its great significance and usage throughout the world. Agustina (2014) claimed ESP as a teaching approach for non-native speakers with respect to different disciplines. In science and medicine the greatest number of published material is in English language and almost all the medical journals are also available in English language.

In recent years, English language became a vital source of transmission of information, in International and American journals. Not only English language is prevalent 
in traditional communication system but also all the computer networking system and WWW operate in English language. Resultantly, the English language becomes the cause of fast export in other language cultures (Frinculescu, 2009). At international level, during the last five years, the field of English for Medical Purposes (EMP) is maintained powerfully. Thus, in the language of medicine, English language attained the position of "Premier research language" (Swales, 2004).

Medical English is considered as context-based and completely technical. Common language, technical language, academic language and jargons are employed by doctors in the workplace. Medical English is different from the General English therefore the method to teach medical English is totally different from the teaching method of fundamental English. The main purpose of learning EMP is the usage of English language regarding career and social relations instead of focusing on basic grammar and sentence structure (Niazi, 2012, p. 51)

\section{English for Occupational Purposes}

English for Occupational Purposes (EOP) is one of the main sub-division of ESP. According to Robinson (1991), "EOP has been divided into three categories" (p. 3-4), that are, Pre-experience, In-Service/Simultaneous and Post-experience. The following figure elaborates the main classification of ESP concerning EAP and EOP:

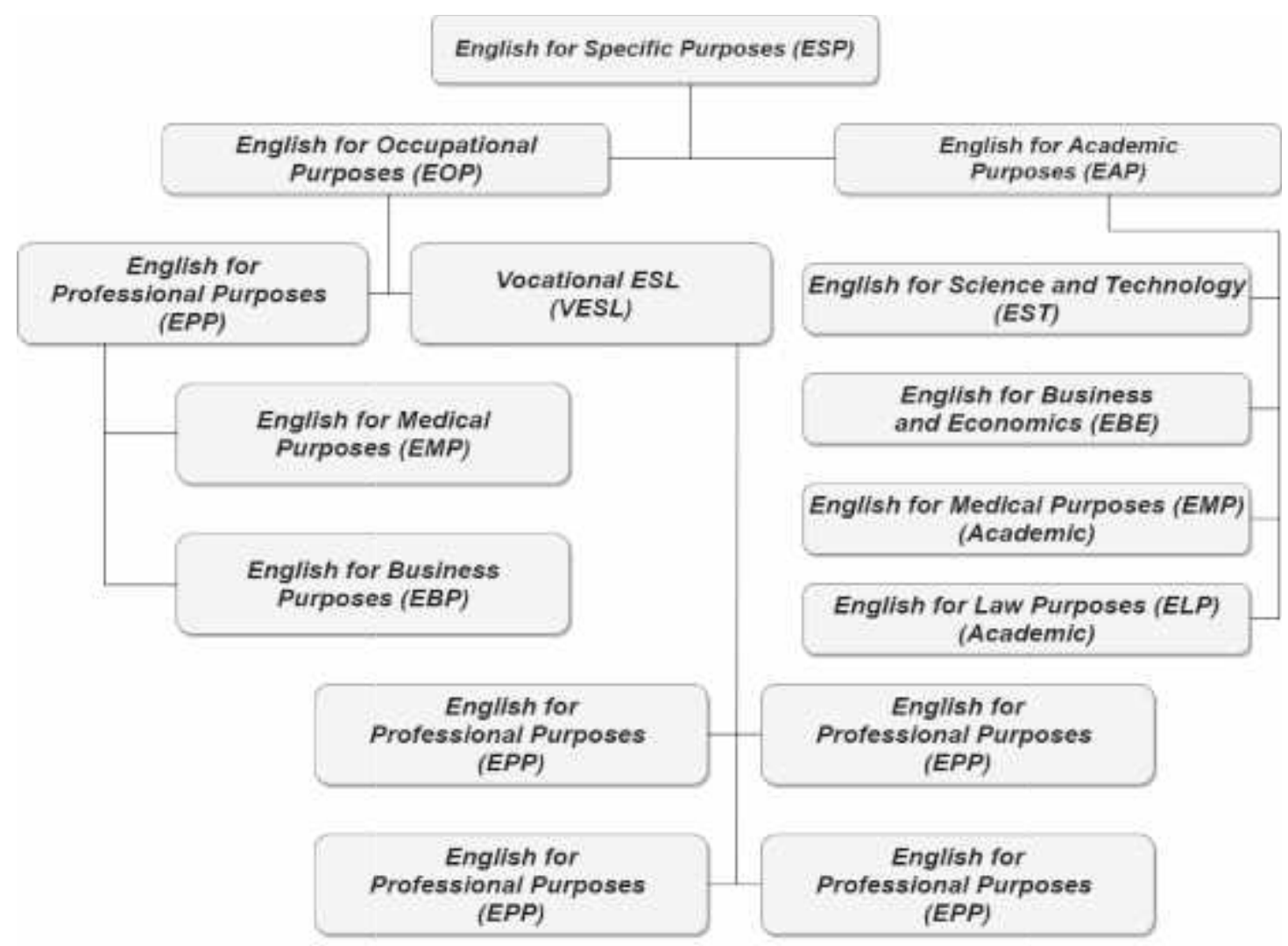

Figure: Classification of ESP categories (after Price- Machado and Johns, 2001, p. 44) 
In order to perform adequately well in the occupational context, at the initial stage ESP focused on the specific needs of the learners and also identifies particular discourse and linguistic features. As by considering this, remedial courses are designed which help learners in the academic context and remedial courses for medical professionals guide them in the occupational context.

\section{Relevant Researches}

In Pakistan, English language has acquired significant position and it is considered a language of communication. In order to meet the specified professional needs of the learners, English language is being taught in various institutions from last some decades. So far, the medical profession is concerned; medical practitioners need English language in their professional context. Different linguists have worked along with this dimension as Donesch-jezo (2014) conducted a research to teach the vocabulary to the medical students by employing different activities in order to meet the professional target settings. In result, these tasks based designed activities in relation to developing vocabulary proved valuable for the students. Similarly, Rahimirad\&Moini (2015) explored the challenges faced by the instructors and students in classroom settings at university with reference to particular disciplines.Likewise, Innocent (2017) designed a needs oriented comprehensive course along with particular activities and lesson plan for the medical students for the State of Benin. This course was comprised of different modules in order to satisfy the linguistic and communicative competence. His primary focus was to stress on the critical thinking and acquiring language through route learning. In this respect, course was developed in light of theory of functional syllabus. Similarly, Rubab\& Masood (2017) explored the linguistic needs of South Punjab students regarding speaking skills and recommended a course to cope up the target situations. On the other hand, (Lodhi et al.,2018) carried out a research in context of ESP for medical students by conducting a survey among the doctors of South Punjab. Their findings explored a need of specific course to cope up the target academic and professional settings of the doctors. Similarly, Nhue, Van \& Long (2018) executed a research on extensive listening for the tourists and suggested various strategies and activities to incorporate in the course of English for tourists. Rubab, Khan \& Masood (2019) designed a course for Social Sciences Learners of Bahauddin Zakariya University Multan by keeping in view the needs of the students of South Punjab. The course was designed in light of eclectic approach covering four skills in EAP classroom settings. Various studies have been conducted in this regard, but a breach was observed to improve the linguistic professional skills of medical officers of Baluchistan.

\section{Materials and Methods}

This study is descriptive research in nature. The aim of the research is to describe the traits of population and explore their linguistic needs.It includes statistical calculations, frequencies, means and standard deviations. It encompasses data collection and later organizes, describes, tabulates and depicts the collected data. Mostly, it employs visual aids such as figures and tables to guide the reader in comprehending the data distribution.Regarding different consideration, the quantitative method approach has been used in this study by the researchers.

The population of this research work was medical officers of hospitals of Quetta, Baluchistan. The sample was taken from Bolan Medical Complex Hospital, Quetta Hospital, 
Akram Hospital, Children's Hospital, Civil Hospital, Saleem Medical Complex, Jilani Hospital, Combined Military Hospital (CMH), Imdad Hospital, and Mohtarma Benazir Bhutto General Hospital Quetta. In this regard, 100 medical officers of these hospitals were conveniently selected in order to analyze the professional language needs. The questionnaire formulated for medical officers comprised of close-ended questions.In formulating questionnaire, the first step was collecting information regarding professional tasks or activities of medical education. Moreover, the previous researches and related literature were also considered and read by the researchers concerning the field of EMP. The inventory was designed and refined after getting information by the process of needs analysis. In pilot study phase, the validity and reliability of the questionnaire was confirmed, after that confirmation, the questionnaire was successfully administered among the selected sample of this research. Following is the detailed description of the questionnaire for the medical officers:

\section{Table 1}

Description of Data Collection Inventory

\begin{tabular}{|c|c|c|c|}
\hline No & Section & Description of Parts & Scale \\
\hline 1 & $\begin{array}{l}\text { Demographic } \\
\text { Information }\end{array}$ & $\begin{array}{l}\text { The researcher asked about } \\
\text { gender, age and medium of } \\
\text { education and communication. }\end{array}$ & $\begin{array}{l}\text { No scale was used for } \\
\text { this section. }\end{array}$ \\
\hline 2 & $\begin{array}{l}\text { Significance of } \\
\text { English Language }\end{array}$ & $\begin{array}{l}\text { In this section, five questions were } \\
\text { designed to ask about the } \\
\text { significance of medical and general } \\
\text { English language in professional } \\
\text { context. }\end{array}$ & $\begin{array}{l}\text { Five points Likert } \\
\text { Scale of importance. }\end{array}$ \\
\hline 3 & $\begin{array}{l}\text { Employing } \\
\text { Language Skills }\end{array}$ & $\begin{array}{l}\text { In this, five questions were } \\
\text { mentioned to know the language } \\
\text { skills of the medical officers in } \\
\text { related areas. }\end{array}$ & $\begin{array}{l}\text { Five points Likert } \\
\text { Scale of Agreement. }\end{array}$ \\
\hline 4 & Lacks and Needs & $\begin{array}{l}\text { Four questions were included in } \\
\text { this section to get information } \\
\text { about lacking and required aspects } \\
\text { of the medical professionals. }\end{array}$ & $\begin{array}{l}\text { Five points Likert } \\
\text { Scale of quality. }\end{array}$ \\
\hline
\end{tabular}

\section{Results and Discussion}

The data was collected from the Medical officers and questionnaire was used as a research tool to collect information from the medical officers. The questionnaire has four sections and each section is classified in sub-items. First section was of demographical information pertaining to the personal information of the medical officers. Second section was related to the significance of English language. Third section was of employing language skills in the medical context. Fourth and last part was of lacks and wants; in it section four statements were designed. This section provides quantitative analysis concerning lacks and needs related to English language in the professional medical context. In order to determine the respondents' opinion, Five point Likert scale was used. 
Table 2

Importance of English Language

\begin{tabular}{cccccccc}
\hline $\begin{array}{c}\text { Importance of } \\
\text { English language }\end{array}$ & $\mathbf{5}$ & $\mathbf{4}$ & $\mathbf{3}$ & $\mathbf{2}$ & $\mathbf{1}$ & Mean & SD \\
\hline $\begin{array}{c}\text { English for Medical } \\
\text { Profession }\end{array}$ & 62 & 14 & 12 & 7 & 3 & 4.27 & 1.11 \\
\hline $\begin{array}{c}\text { Comprehending } \\
\text { Medical Terminology }\end{array}$ & 58 & 24 & 10 & 4 & 2 & 4.34 & .96 \\
\hline $\begin{array}{c}\text { Pakistani Medical } \\
\text { Discourse }\end{array}$ & 46 & 18 & 10 & 11 & 12 & 3.74 & 1.47 \\
\hline EMP Course & 12 & 63 & 11 & 8 & 4 & 3.72 & 0.92 \\
\hline $\begin{array}{c}\text { English Language } \\
\text { Skills }\end{array}$ & 14 & 69 & 6 & 5 & 3 & 3.88 & 0.82 \\
\hline
\end{tabular}

The above findings showed that good number of the medical officers mentioned that English language was extremely important, majority of the respondents believed that it was important for them in the medical profession. Others reported that English language was somehow important, while ratio of the respondents for minimal important and not at all important is very few. Thus, the overall data in the above table clearly depicts that English language is quite significant and rated as very important at professional level in the medical context.

Table 3

Employing Language Skills

\begin{tabular}{cccccccc}
\hline Employing & SA & $\mathbf{A}$ & $\mathbf{N S}$ & $\mathbf{D}$ & SD & Mean & SD \\
\hline Language Skills & $\mathbf{5}$ & $\mathbf{4}$ & $\mathbf{3}$ & $\mathbf{2}$ & $\mathbf{1}$ & $\mathbf{0}$ & \\
\hline $\begin{array}{c}\text { Daily } \\
\text { Conversations }\end{array}$ & 46 & 31 & 12 & 9 & 0 & 4.16 & .97 \\
\hline $\begin{array}{c}\text { Discussion on } \\
\text { Medical Issues }\end{array}$ & 12 & 65 & 9 & 8 & 4 & 3.74 & .92 \\
\hline $\begin{array}{c}\text { Seminars \& } \\
\text { Conferences }\end{array}$ & 65 & 10 & 12 & 6 & 5 & 4.26 & 1.19 \\
\hline $\begin{array}{c}\text { Writing Research } \\
\text { Paper }\end{array}$ & 72 & 12 & 9 & 4 & 1 & 4.53 & .89 \\
\hline $\begin{array}{c}\text { Reading Articles } \\
\text { \& Journals }\end{array}$ & 21 & 43 & 23 & 8 & 3 & 3.72 & .99 \\
\hline
\end{tabular}

The results in above table revealed that majority of the medical officers strongly agreed and agreed regarding employing English language skills in the professional medical context. On the other hand, some of the respondents were not sure, disagreed and strongly disagreed in employing English language skills in the medical context. Hence, the overall mean value of almost all areas of employing English language skills is above table 3, so it indicates that most of the medical officers opined that they employ English language skills in the above mentioned areas regarding professional medical field. 
Table 4

Lacks and Needs

\begin{tabular}{|c|c|c|c|c|c|c|c|}
\hline \multirow[t]{2}{*}{$\begin{array}{c}\text { Lacks \& } \\
\text { Needs }\end{array}$} & \multicolumn{5}{|c|}{ Frequency } & \multirow[t]{2}{*}{ Mean } & \multirow[t]{2}{*}{ SD } \\
\hline & $\begin{array}{c}\text { Always } \\
5\end{array}$ & $\begin{array}{c}\text { Very } \\
\text { Often } \\
4\end{array}$ & $\begin{array}{c}\text { Not } \\
\text { frequent } \\
3\end{array}$ & $\begin{array}{c}\text { Seldom } \\
2\end{array}$ & $\begin{array}{c}\text { Never } \\
1\end{array}$ & & \\
\hline $\begin{array}{l}\text { Not able to } \\
\text { appropriately } \\
\text { communicate } \\
\text { on medical } \\
\text { related topics }\end{array}$ & 25 & 17 & 16 & 11 & 29 & 2.97 & 1.58 \\
\hline $\begin{array}{l}\text { Not able to } \\
\text { well } \\
\text { comprehend } \\
\text { medical } \\
\text { scripts \& } \\
\text { articles }\end{array}$ & 32 & 8 & 19 & 17 & 22 & 3.11 & 1.57 \\
\hline $\begin{array}{c}\text { To } \\
\text { comprehend } \\
\text { medical } \\
\text { based } \\
\text { instructions }\end{array}$ & 18 & 32 & 17 & 17 & 14 & 3.23 & 1.33 \\
\hline $\begin{array}{c}\text { To } \\
\text { understand } \\
\text { written case } \\
\text { histories } \\
\text { (medical) }\end{array}$ & 48 & 25 & 10 & 13 & 2 & 4.06 & 1.14 \\
\hline
\end{tabular}

In the above table, the findings are quantitatively presented regarding lacks and needs of the medical officers in the professional medical context. The above findings revealed that medical officers quite often fail to communicate effectively in English language on medical related topics. Moreover, the medical officers face multiple problems in developing good understanding concerning medical scripts, articles, medical based instructions and case histories of medical presented in the English language.

\section{Findings and Discussion}

The findings revealed that $62 \%$ medical officers strongly agree that the significance of required English language competence was important in order to perform professional tasks and activities. On the other hand, 63\% medical officers agree that the significance of English language for the medical profession was important. In the context of comprehending medical terminologies 58\% respondents strongly agree that it was important. While, 69\% medical officersagree that English language skills was important in the professional medical context.46\% medical officers strongly agree that in medical discourse community of Pakistan, English language was important. On the other hand, $65 \%$ medical officers strongly agree that English language was definitely used in seminars and conferences of the medical field. $46 \%$ medical officers agree that English language was 
greatly used in daily conversations and communication in the professional medical context. $65 \%$ medical officers strongly agree that English language is used as a spoken medium in meetings for discussion on medical issues. Similarly, 72\% medical officers agree that English language was employed in writing medical research paper. The perception of $25 \%$ medical officers revealed that they are not able to communicate appropriately in English language on medical related topics. The responses of $32 \%$ medical officers showed that mostly they had difficulties in comprehending medical scripts, articles and all related published material that are in English language. The answers of 18\% medical officers depicted that they always need English to comprehend medical based instructions provided in the English language. The responses of $48 \%$ medical officers revealed that they need proficiency in English to understand written case histories of medical, in order to write new case histories that are all in English language.

With reference to this question; what are the English language needs of the medical officers in their professional context? The findings revealed that the majority of the medical officers believed that English language was important for them as well as for the medical students. The responses make it clear that English language was essential and important concerning medical discourse community of Pakistan. The medical officers indicated that in the medical profession, all language skills are equally important. The overall findings of the responses by the medical officers depicted that English language was employed in multiple professional medical activities like communication with doctors and different health professionals, to participate in conferences and seminars for research paper writing, writing medical scripts (prescriptions) and taking case histories, to comprehend the manuals regarding medical equipment and to read medical literature published in English language. Regarding the medical representative in Pakistan, English acquired the status of the official language. They are required to communicate and interact with the educated class in the English language. They need to perform their occupational tasks such as, presentations, meetings and briefings in the English language. English language plays pivotal role in the medical professional context. Medical officers (representatives) need to interact with colleagues, professional trainers, officers and medical organizations in the English language. As English has acquired the status of international language, therefore for using English language in medical professional activities, the medical officers (representatives) need to be competent (Afzal, Awan and Khan, 2016, p. 45). EMP was a sub-branch of ESP. In order to learn medical English, the students and medical doctors had multiple reasons. One of the reasons was that the medical students need English language for the academic tasks whereas medical officers and doctors need English language in order to communicate with colleagues, to write research papers for publication, to participate in international conferences, to go for further studies in foreign countries and also doing jobs in foreign hospitals where English has the status of a first language (Kawagoe, 2009).

In context of this question; what kind of ESL course can be designed relying on the information of the present study? The findings revealed that the medical officers mentioned that in medical colleges, EMP course should be introduced. They recommended in final year of MBBS, practical based learning of English language. The course content needs to be communication skills, writing (prescriptions, research papers etc.,) and comprehending case histories, seminar skills, presentation skills regarding medical conferences and comprehending medical related topics. The purpose of practical based 
English in final year was to learn practical usage of English language while focusing on the professional medical aspects instead of just learning general English.

\section{Conclusion}

The conclusion of the research study was based on the findings that were acquired from the data provided by the medical officers. The medical officers had multiple reasons for learning English language regarding the professional medical field. In the professional context, the medical officers are required to perform multiple tasks effectively like reading medical texts, participating in conferences as well as seminars and communicative needs. Concerning an international community of medicine, the English language has acquired the status of Lingua Franca. In the professional context, majority of the doctors go abroad for good job settings and in most of the foreign countries English language is the medium of communication, thus; this situation breeds a strong need of the EMP course. The doctors and medical officers, face many problems in the professional field due to their not up to the mark competence in English language skills. However, it is important and essential to impart the appropriate English competence skills among the medical officers and doctors.

\section{Recommendations}

Following are some recommendations for developing a course of English for medical purposes:

- The study reveals that the medical officers were not satisfied with their familiarity of English language skills concerning the professional context. So, an EMP course needs to be introduced in order to meet the professional needs of the medical discourse community.

- A practical based medical English course should be introduced in the final years of the MBBS study. EMP course needs to be designed while considering specifically the professional requirements of the medical officers so that they can conveniently adapt it.

- Different areas of language needs must be explored while carrying the process of needs analysis. ESP practitioners can be involved in it, while conducting it on a general scale.

- Further, research study must be conducted on different levels in the field of medical. A course of English language needs to be designed and classified according to the preclinical and clinical needs. Likewise, different areas of the medical profession such as medicine, nursing, surgery and medical discourse can be encompassed.

- Regarding continuous and frequent up to the mark professional development of doctors, the workshops of the English language and refresher courses must be introduced in the field of medical. 


\section{References}

Agustina, T. (2014).English for Specific Purposes (ESP): An Approach of English Teaching for Non-English Department Students. Beta, 7(1), 37-63.

Bailey, N. (2000). E pluribus unum: Health as content for a community of learners. In M. Pally (Ed.), Sustained content teaching in academic ESL/EFL: A practical approach (pp. 179-199). Boston: Houghton Mifflin.

Brown, J. D. (1995). The elements of language curriculum: A systematic approach to program development. Boston, Massachusetts: Heinle\&Heinle Publishers.

Crystal, D. (1996). The Cambridge encyclopedia of English language.Cambridge, Great Britain: CUP.

Dudley-Evans, T., \& St. John, M. J. (1998).Development in English for specific purposes: A multi-disciplinary approach. Cambridge: Cambridge University Press.

Frinculescu, I. C. (2009).The Physiology of English as a Lingua Franca in Medicine.Fiziologia Physiology, 19(2), 4-7.

Holmstrom, B. A. S. (2005). English in Medicine.Cambridge: CUP.

Hutchinson, T., \& Waters, A. (1987).English for specific purposes: A learning-centered approach. Cambridge: Cambridge University Press. https://doi.org/10.1017/CBO9780511733031

Johns, A. M., \& Dudley-Evans, A. (1991). English for specific purposes: International in scope, specific in purpose. TESOL Quarterly, 25(2), 116, 297-314. https://doi.org/10.2307/3587465

Kang, S. J. (2004). A Korean medical doctor's experiences in learning and use of English in the United States: Individual and environmental affective factors. Paper presented the Sixteenth Annual Conference in Ethnography.

Kawagoe, E. (2009). English for Specific Purposes in Medical and Nursing Schools.The Proceedings of the 49th JACET Annual Convention Programs.

Khan, A. M. A., Awan, A. G., \& Afzal, M. I. (2016).Designing an ESP course for medical representatives in Pakistan.Research on Humanities and Social Sciences, 6(13).

Kurfurst, P. (2004). English as a lingua franca of medicine.The International Conference on English Is Not Enough: Language Learning in Europe. Olomouc, Czech Republic.

Mackay, R. (1978). Identifying the nature of the learner's needs. In R. Mackay \& A. J. Mountford (Eds.), English for specific purposes: A case study approach (p. 2137). London: Longman. 
Maher, J. (1886). The development of English as an international language of medicine.Applied linguistics, 7(2).ijel.ccsenet.org International Journal of English Linguistics Vol. 8, No. 5; 2018214

Master, P. (2005). Research in English for specific purposes.In E. Hinkel (Ed.), Handbook of research in secondlanguage teaching and research (pp. 99-115). Mahwah, NJ: Lawrence Erlbaum.

Niazi, M. M. (2012). English for medical purposes: A case of English for specific purposes. National Universityof Modern Languages, Islamabad, Pakistan.

Nhue, N. T. Q., Van, T. T. \&Long, N. V. (2018). Extensive Listening in ESP: An Experiment in the Course of "English for Tourism 2" at Dalat University. VNU Journal of Science: Education Research,34(4), 1-13.

Ramirez, C. G. (2015). English for specific purposes: brief history and definitions. Revista de LenguasModeRnas, (23), 379-386.

Rahimirad, M. \&Moini, R.M. (2015).The Challenges of Listening to Academic Lectures for EAP Learners and the Impact of Metacognition on Academic Lecture Listening Comprehension. Sage Open, 1-9.

Richards, J. C., Platt, J., \& Platt, H. (1992).Dictionary of language teaching and applied linguistics. Malaysia:Longman.

Robinson, P. (1991). ESP today: A practitioner's guide (pp. 1-21). New York: Prentice Hall.

Rubab, I., Masood, F. \& Afzal, B. (2017). Exploring the Academic English Speaking Competence of Social Sciences Students at Higher Level: A Case of Southern Punjab. Pakistan Social Sciences Review, 1(2), 113-124.

Rubab, I., Khan, M. Y., \& Masood, F. (2019). Academic English Language for Social Sciences Learners: A Case of BahauddinZakariya University Multan. Pakistan Social Sciences Review, 3(1) 180-193.

Donesch-jezo. E., \&pachonska-wolowska, A. (2014). Teaching of vocabulary to medical students in ESP Courses. An International Peer-Reviewed Open Access Journal. 1(1). 72 87.

Smoak, R. (2003). What is English for specific purposes? English Teaching Forum Online, (2), 22-27. Retrieved October 6, 2013, http://americanenglish.state.gov/files/ae/resource_files/03-41-2-g.pdf

Swales, J. (2004).Research genres: Explorations and applications. Cambridge: Cambridge University Press.https://doi.org/10.1017/CB09781139524827 